\title{
Assessing the Natural Resource Use and the Resource Efficiency Potential of the Desertec Concept
}

Originally published as:

Tobias Samus, Bastian Lang, Holger Rohn (2013):

Assessing the Natural Resource Use and the Resource Efficiency Potential of the Desertec Concept

In: Solar Energy, vol. 87, pp. 176-183

DOI: 10.1016/j.solener.2012.10.011

This is the author's version of a work that was accepted for publication. Changes resulting from the publishing process, such as editing, corrections and structural formatting, may not be reflected in this document. Changes may have been made to this work since it was submitted for publication. A definitive version was subsequently published in the Journal cited above. 


\author{
Assessing the Natural Resource Use and the Resource Efficiency \\ Potential of the Desertec Concept \\ Tobias Samus ${ }^{\mathrm{a}}$, Bastian Lang ${ }^{\mathrm{b}}$, Holger Rohn ${ }^{\mathrm{a}}$ \\ ${ }^{a}$ Wuppertal Institute for Climate, Environment and Energy, P.B. 100480, 42004 \\ Wuppertal, Germany \\ ${ }^{b}$ University of Kassel, Institut für Produktionstechnik und Logistik, Umweltgerechte \\ Produkte und Prozesse, 34125 Kassel
}

\title{
Corresponding author
}

Tobias Samus; c/o Klaus Wiesen, Wuppertal Institute for Climate, Environment and Energy, P.B. 100480, 42004 Wuppertal, Germany; tobias_samus@hotmail.com; phone: +49179-82 98 604; fax: +49-202-2492-138

\section{Highlights}

$>$ Aim is to assess the resource efficiency (RE) potential of Desertec. > First: analysis of different CSP plants and HVDC transmission from MENA to Europe. > Using this for MIPSbased assessment of Germany's mainly renewable 2050 fuel mix. > RE potential differs between $50 \%$ and $80 \%$ compared to a conventional fuel mix. > Central receiver plants are assessed as the most resource efficient ones.

\section{Keywords}

Natural resource use; resource efficiency; MIPS; CSP/solar power; Desertec; MaRess

\section{Abstract}

Considering global warming, increasing commodity prices, and the dramatic consequences of the over-exploitation and overuse of resources, a transition to a renewable energy supply is necessary. This requires an (resource) efficient and renewable supply of operating reserve.

In this article, a possible solution to this problem is analysed: the Desertec concept. It is meant to convert solar energy in areas with high solar irradiation into electrical energy by means of Concentrated Solar Power (CSP) transferring this energy by High Voltage Direct Current (HVDC) lines into the whole European Union Middle East and North Africa (EUMENA) area. In order to assess the resource efficiency potential of Desertec, three different kinds of CSP plants (parabolic trough, Fresnel collector and central receiver of the building classes Inditep, Novatec and Solar Tres) including heat storage systems (Molten Salt and Phase-Changing-Material) and the necessary HVDC are analysed using the Material Input per Service Unit (MIPS) methodology. The assessment is accomplished for three different locations (Morocco, Tunisia and Egypt) and two points of time (2025 and 2050). With these results, a scenario of electricity supply in Germany in 2050 with a $20 \%$ share of solar power import is calculated.

Central receivers are the most resource efficient ones: their consumption of abiotic materials is only half of parabolic trough plants and two thirds of Fresnel trough plants. Water and air consumption is the lowest of all analyzed CSP plants as well.

The scenario for Germany's fuel mix in 2050 shows that a predominantly renewable fuel mix reduces the consumption of abiotic materials by $75 \%$, of water by $60 \%$ and of air by $45 \%$. Only the consumption of biotic materials rises due to the higher share of biomass conversion. 


\section{Introduction}

Climate change is anthropogenic as identified by the IPCC (IPCC 2007). It is amongst others caused by the combustion of fossil fuels for energy supply. For instance, electrical energy accounts for $24 \%$ of the worldwide greenhouse gas (GHG) emissions (bpb 2008). At the same time fossil energy sources run short - e.g. the IEA expects the so-called 'peak oil' (the maximum point of the global petrol extraction) to occur 2035 the latest (IEA 2010). It is essential to change the energy supply towards renewable energy sources. But besides meeting the pure amount of energy demanded, the allocation of grid services - especially operating reserve - is of immense importance. Grid services are different kinds of services, which energy producing companies allocate to the transmission system operators. These services are either essential for stabilizing the electrical grid during use or for rebuilding the grid after the occurrence of major faults such as power outages. An example for such services is the operation reserve, which is used to meet the fluctuating demand for electricity at any time with the same amount of electricity 'produced'. For example, gas power plants are able to react to a sudden rise in energy demand - or a sudden cut in energy supply from fluctuating sources such as wind energy - by adapting their power production within seconds. Amongst others, concentrating solar power (CSP) in combination with thermal storage can fill this gap. While photovoltaic cells make use of a physical phenomenon occurring in semiconductors hit by photons, CSP uses concentrated solar irradiation in order to heat a heat transfer fluid and insert this heat energy into a conventional steam turbine system. Since heat may be stored rather easily compared to electrical energy, CSP are able to provide electricity even in times without solar irradiation.

But emissions of GHG are not the only urgent environmental issue: the resource use of humanity is exceeding the natural bounds of planet earth by almost the factor 1.5 (WWF 2010). Thus, while solving the energy supply problem, it is necessary to cut the resource use as well.

The Desertec concept brings up the idea of 'harvesting' renewable energies like solar irradiation and wind at the best locations and transferring it into the demand centres (Desertec Foundation 2009). Especially one plan within the Desertec concept has gained a lot of attention: Converting the intense solar irradiation in the Middle East and North Africa (MENA) region into electricity by means of CSP for local and European use. It is planned to transmit this electricity into the European grid, i.e. the Network of Transmission System Operators for Electricity (ENTSO-E) grid, by high voltage direct currents (HVDC) lines.

There are already some studies related to the Life Cycle Assessment (LCA) of CSP and the import of solar power into the European grid. An LCA based on ISO 14000 aims at assessing the environmental impacts of a product or service within all the stages of a product's life cycle (raw material extraction, material processing, manufacturing, distribution, use, repair and maintenance, and disposal or recycling). There are several aspects of environmental impact which may be assessed, but the most common ones are greenhouse gas emissions, eutrophication, acidification, ozone depletion, photochemical smog formation, and land use. However, these aspects do not allow assessing the resource use in a systematic way.

One of the oldest studies is a MIPS (Material Input per Service Unit) analysis of an $80 \mathrm{MW}$ parabolic trough power plant (type SEGS - Solar Electricity Generating Systems) conducted by the Wuppertal Institute 1996 (Lehmann et al. 1996). MIPS is an approach to compare the resource use of different products and services. For a more detailed discussion of MIPS, please refer to chapter 2 - methodology. Lehmann et al. 1996 compared different modes of operation (solar only and hybrid) and cooling (wet and dry) using the same methodology (MIPS) as this study. Since it analyzed a rather outdated CSP technology the significance for today's decisions is relatively small. 
Later on, LCAs followed of different CSP plants: Weinrebe analyzed the central receiver plants of type PHOEBUS (Weinrebe 2000). Within the Sokrates project, Viebahn conducted an LCA of two different parabolic trough CSP (SEGS with LS-3 collectors and direct steam generation, DSG) and a Fresnel trough CSP (Viebahn 2004). Based on this, May analyzed the import of solar power from North Africa to Europe using HVDC-lines while putting the focus on the route of the power lines (May 2005). She made use of the LCA methodology as well. Tressner conducted an LCA of parabolic trough (SEGS and DSG), Fresnel (Solarmundo) and central receiver (Phoebus) CSP, partially also based on Viebahn 2004 (Tressner 2007). Fricke assessed the environmental input of a central receiver plant making use of the MIPS and embodied energy methodology (Fricke 2007). The most recent LCA of up-to-date CSP technologies was conducted within the scope of the NEEDS project (New Energy Externalities Developments for Sustainability). The NEEDS project was aimed at identifying the full costs (economic and ecological) and benefits (i.e. direct and external) of future energy systems and related energy policies at national and European level. The study on CSP focussed on different options of available large scale technologies, which have been demonstrated in practice already: parabolic trough (Andasol I and DSG Inditep), Fresnel trough (Novatec) and central receiver (SolarTres). Besides comprising inventories of the specific input materials for each plants and conducting an LCA, the study also analyzed the future technology development (Viebahn et al. 2008).

A cross-evaluation of existing studies shows that there are three main gaps in the assessment of solar import to Europe based upon up-to-date CSP technologies: Firstly, the LCAs do not allow to assess the natural resource use of such solar import; secondly, most of the studies are either too old or do not comprise all relevant technology options - Viebahn et al. 2008 is an exception from the latter; thirdly, the existing studies do not put focus on developing or taking up scenarios for the future fuel mix development. The data availability for life-cycle-wide material inventories for CSP and its extrapolation into future seems sufficient, though.

This article presents an estimation of the natural resource use within the Desertec project based on the MIPS methodology. It also includes an assessment of the resource efficiency (RE) potential which is based on a scenario for the German fuel mix in 2010 and 2050. The Desertec concept is assumed to include CSP only. It should be noted that the results of this analysis are geographically sensitive in terms of the CSP locations.

The estimation was made in the framework of the MaRess (material efficiency and resource conservation) work package (WP) 1 which induced 19 other analyses of the natural resource use of selected products, services and technologies (including e.g. offshore/onshore wind power, biomass, photovoltaic cells) (Rohn et al. 2010, Lang-Koetz et al. 2010). The MaRess project was conducted by a joint venture of several German research institutions and universities and examined different aspects of material efficiency and resource conservation in Germany, e.g. resource efficiency analyses, resource conservation policies, assessment of critical resources, etc. Detailed results are available online (ressourcen.wupperinst.org/en).

\section{Methodology}

For assessing the natural resource use of the Desertec concept, the Material Input per Service Unit (MIPS) methodology was used. MIPS allows to estimate the life-cycle-wide material input of a product or service including supply chains and thus matches the aim of this study, i.e. assessing the natural resource use of the Desertec concept. On the other hand, MIPS does not allow assessing the output-related environmental impacts. But since these are assessed sufficiently within the existing LCAs, the focus of this study is met when using the MIPS methodology. 
MIPS was first introduced in the early 1990ies by Friedrich Schmidt-Bleek (Schmidt-Bleek et al. 1994). It is an input oriented indicator for resource use defined as "life-cycle-wide input of natural resources (MI), which is required to fulfil a human desire or need (S) by technical means" (Lettenmeier et al. 2009). The basic idea behind MIPS is that measuring the environmental performance of products and services with output categories (e.g. GHG emissions, ecotoxicity, etc.) is rather difficult due to the huge amount of possible outputs. But since all outputs arise from inputs there is an alternative: The assessment of inputs, i.e. energy and mass, is easier and allows as well a reliable estimation of the ecological impact of a product or service.

The MIPS concept differentiates between five categories of material use: abiotic materials, biotic materials, water, air and erosion. MIPS is calculated by multiplying the inputs (e.g. energy, masses) by their material intensity (MI) (unit: mass unit per input unit, e.g. $\mathrm{kg} / \mathrm{kg}$ or $\mathrm{kg} / \mathrm{kW} \mathrm{h}$ ) and summing up all categories. Dividing these sums by the defined service unit (e.g. $\mathrm{kW} \mathrm{h}$ el, pieces of product, etc.) gives the MIPS values:

$$
\begin{aligned}
& \operatorname{MIPS}(x)=\frac{\sum_{i=0}^{n} m_{i} \cdot M I_{i}}{U s e(x)} \\
& \text { where: } \\
& X \quad \text { product/service } \\
& \operatorname{MIPS}(x) \quad \text { MIPS value of } x \\
& \mathrm{~m}_{\mathrm{i}} \quad \text { amount/mass of input } \mathrm{i} \\
& \mathrm{n} \quad \text { number of inputs } \\
& \mathrm{Ml}_{\mathrm{i}} \quad \text { material intensity of input } \mathrm{i} \\
& \text { Use }(x) \quad \text { useful service of product } x\left(\text { e.g. } k W h_{e l}\right)
\end{aligned}
$$

The Ml factor estimates the amount of inputs in advance that have been necessary in order to provide a certain material, energy or service. Table 1 gives an example of how material input and the related material input factors for the corresponding materials may look like. It presents the top ten input materials according to their share in the use of the MIPS category abiotic materials and the corresponding material intensity factors.

Note that erosion was not included in the following assessment since it mainly appears with biotic materials. Additionally, the use of biotic material has shown no significant share in the resource use of CSP plants at all, therefore being not included in the presentation and discussion of the results.

\section{Approach}

Since Desertec is rather a concept than a plan of implementation it is necessary to create a scenario in order to assess its natural resource use. Below, the three main steps are presented: CSP inventory, Desertec scenario and German fuel mix.

\subsection{Inventory data of CSP plants \& HVDC line}

Starting points are the life cycle inventories from Viebahn et al. (2008) comprised within the scope of the NEEDS project, which conducted research on the economic and environmental costs (direct and external) of future energy systems. Life cycle inventories comprise the input materials and services, and the corresponding amounts of a product or service over their complete life cycle. Note that the NEEDS life cycle inventory of the Fresnel trough power plant Novatec only covers the solar field. These data are complemented by inventories of the other components of the parabolic trough data to fill this gap, since the main difference between parabolic and Fresnel troughs is the solar field. Note that this approach will probably overestimate the water use of the Novatec Fresnel trough, for this 
trough technology uses an automated dry cleaning system with minimized water consumption. However, since the used inventory data is based on the first prototype PE 1 where this cleaning system was not installed yet during the time of the generation of the inventory data - details on the water savings due to the automated cleaning system are not available.

These inventories of three existing CSP plants - parabolic trough of building class Inditep, Fresnel trough of building class Novatec and central receiver of building class Solar Tres are complemented by thermal storages. Note that the Solar Tres concept has been put into commercial practice at the Gemasolar power plant in Spain recently. Phase Changing Material (PCM) storages with potassium nitrate as heat storage medium are added to the trough plants while molten salt storage is added to the central receiver plant (which uses potassium nitrate as a heat transfer medium). These plants were chosen for different reasons: Most important, they are all plants already implemented thus they all proved their functionality; furthermore, they represent all three large-scale CSP technologies (parabolic, Fresnel, central receiver); the direct steam generating trough plants were chosen since it seems a reasonable assumption that saving the heat transfer oil in conventional CSP and the higher total efficiency will have this technology displace the oil-based trough technology.

The specifications for the CSP plants are taken from the "optimistic-realistic" scenarios in Viebahn et al. (2008). This scenario is based on the main assumption, that CSP will amongst other renewable energies - have its breakthrough in terms of market diffusion and will experience major cost and material input reduction due to effects of mass production and technology development. This assumption is based on moderately optimistic subassumptions on the implementation of different instruments supporting the diffusion of renewable energy technologies (e.g. feed-in-laws, increasing fossil fuel prices, power purchase agreements). Table 2 shows the specific assumptions on CSP of the "optimisticrealistic" scenario. Note that the load of central receivers does not upscale with time due to the fact that $180 \mathrm{MW}_{\mathrm{el}}$ was calculated as design optimum (Viebahn et al. 2008). In order to increase the forecasting accuracy for the future technology development, the inventory data is updated in two steps for the years 2025 and 2050.

May (2005) gives a detailed analysis of three possible inland locations and corresponding $800 \mathrm{kV}$ HVDC lines (combining geographical, political, sociological and cultural data for the calculation of the power line route) including inventory data. These routes were confirmed to be representative in Trieb et al. (2009). Since recent implementations of CSP plants in MENA are all located at (or close to) the coast, the locations and lines from May (2005) are alternated accordingly (see Table 3). Furthermore, May used locations with intensive irradiation for her LCA with annual solar irradiation rates of more than $2,800 \mathrm{kWh} /\left(\mathrm{m}^{2 *} \mathrm{a}\right)$. In the present study, a less intensive irradiation was chosen in order to not overestimate the power output and thus give a more conservative estimation in general.

The CSP inventories are accordingly adapted to the new locations in terms of size of the solar field and transportation need. Some other changes are made (e.g. grounding).

Boundaries for the MIPS calculations of the single plants are the borders of the power plant areas - i.e. streets and other power plant related infrastructures are not taken into account. In contrary, the boundaries for the MIPS calculations of the whole Desertec concept (including the HVDC lines) are the connection points to the European grid (see below), thus including also parts of the infrastructure.

\subsection{Desertec scenario}

As pointed out above, there is no implementation plan for Desertec yet. Therefore, a scenario was created based on the implementation scenario in DLR (2006) which assumes that the building-up proceeds in $5 \mathrm{GW}_{\mathrm{el}}$ steps. One step includes a power line with $5 \mathrm{GW}_{\mathrm{el}}$ 
transfer capacity and CSP plants of $5 \mathrm{GW}_{\text {el }}$ summed up power output. Table 4 shows the relevant assumed steps to a final output of $20 \times 5 \mathrm{GW}_{\mathrm{el}}=100 \mathrm{GW}_{\mathrm{el}}$ : Starting the implementation in 2020, in 2030 already eight of these steps will be implemented. Within the following twenty years, further twelve of the steps will be taken to meet the goal of $20 \times 5 \mathrm{GW}_{\mathrm{el}}$ steps in 2050. The scenario is complemented by data of transportation losses (overhead line: $2.5 \%$ per 1,000 km; subsea cable: $1.7 \%$ per $1,000 \mathrm{~km})$ and transformation losses $(0.5 \%$ per transformation) which were taken from Hendriks et al. (2004) and May (2005). Afterwards, the Desertec data is combined with the CSP from the three locations at two dates by calculating how many CSP are necessary to meet the transfer energies (including losses).

Boundaries for the Desertec scenarios are the ENTSO-E grid. This means, necessary constructions at the network connection points (e.g. transmission station) are not included.

\subsection{Fuel mix in Germany}

In order to assess the RE potential of a solar power transfer from MENA to EU it is necessary to consider its function in the fuel mix: base load. Aiming at the base load segment seems a reasonable assumption - which was made by other studies as well (e.g. DLR 2006, Viebahn et al. 2008) - since CSP plants with storages own the ability to target this segment and it will give them a higher economic turnover. To consider its function, it is necessary to estimate the (possible) future fuel mix and to compare it with the current fuel mix. The comparison is based on the natural resource consumption of the German fuel mix in 2008 (Wiesen 2010, BMU 2009) and on scenarios of the mix in 2010 and 2050 (DLR 2006). The latter ones are complemented by some additional assumptions (e.g. concerning biomass composition). The 2010 scenario fuel mix is chosen because of the fact that it is based on the same assumptions as the 2050 scenario and the Desertec implementation scenario. It seems beneficial to choose a consistent set of scenarios in terms of assumptions. Nevertheless, the 2008 fuel mix is still a good basis of comparison since it is the most up to date 'real' fuel mix. For the resource use assessment of the $2050 \mathrm{mix}$ the calculated MIPS value of Desertec is used for 'import solar' which has a share of $20.3 \%$ in the fuel mix (see Table 5 and Figure 1). In order to allow a comparison of the three analysed CSP building classes the $2050 \mathrm{mix}$ is calculated homogenously, i.e. Desertec consists of parabolic troughs, Fresnel troughs or central receiver plants only.

\section{Resource use - results and discussion}

Below, the main findings of the assessment are presented. This includes a detailed discussion of the resource use of the CSP plants, of Desertec, and of the German fuel mix in 2050.

\subsection{CSP plants}

Figure 2 shows a comparison between the three analysed CSP building classes at the Moroccan location in the year 2025, which is representative for all other calculated locations. This is also the basis for all following examinations.

Main finding is the lower resource intensity of central receiver plants. The higher efficiency was a key result of Viebahn et al. (2008) as well, even though another methodology was used (Life Cycle Assessment) which examined a different set of environmental impacts (green house gas emissions, $\mathrm{NO}_{\mathrm{x}}$, non-methane volatile organic compounds, $\mathrm{SO}_{2}$, particulate matters, land use). Since the building classes highly differ in terms of type and amount of used materials, it is not possible to estimate what causes the good performance of central receiver plants without further analyses.

The Fresnel trough plant uses fewer resources than the parabolic trough mainly because of a lighter frame construction of its troughs which is not compensated by its lower efficiency. Note that the higher water use is caused by the assumption of a non-automated cleaning 
system of the Fresnel trough (see section 3.1). This finding shall therefore not be overstretched when drawing conclusions.

The resource use composition of the examined central receiver plant at the Moroccan location in the year 2025 shows that Potassium nitrate has the biggest impact in terms of abiotic material and air use (see Figure 3). Potassium nitrate is the heat transfer fluid and heat storage medium of this plant - the 'molten salt'. 'Conventional' water is mainly used for cooling purposes and also for receiver cleaning. Note that only wet cooling towers could be modelled for the calculations due to a lack of consistent data on climate dependency of water use of dry cooling towers. Thus, the real water consumption and its share in resource consumption will be lower (for more information see Dersch and Richter 2010). Demineralised water is used in the steam turbine section only.

Regarding the resource use composition of a parabolic trough plant, the main conclusion is that $70 \%$ of abiotic resource use is caused by the 'Top 3' consumers: excavation, conventional water and potassium nitrate (see Figure 3). The excavation derives from grounding. Assumptions on grounding are based on Viebahn (2004) and Viebahn et al. (2008) and result from original data. Since it is supposed to be rather dependent on ground type its share may vary. The air use - which is caused by combustion processes and therefore coupled to GHG emissions - is caused mainly by potassium nitrate, aluminium and steel production. Aluminium and potassium nitrate result from the heat storage only.

The composition of the resource use of a Fresnel trough plant (see Figure 3 ) is very similar to the one of the parabolic trough plant because of a similar plant technology (except for the trough concept). The higher share in air use of aluminium in favour of a lower one of steel arises from the change in frame construction: Fresnel troughs weigh less than parabolic troughs. Additionally, the bending stress from wind is smaller due to a smaller surface being exposed to wind. In turn, it is possible to substitute steel by aluminium as frame material.

\subsection{Desertec scenario}

Table 6 shows the calculated MIPS values for the estimated Desertec scenarios. As stated above, three homogeneous (in terms of CSP building class) scenarios are calculated. It is no surprise that the comparison of these Desertec scenarios mirrors the comparison of CSP building classes. The main finding is that the HVDC lines do not have a significant share in the overall resource use at all - e.g. $0.63 \%$ in abiotic materials in the central receiver plant scenario. In order to be able to classify the calculated MIPS values, here are given some conventional plants: natural gas plants consume $234 \mathrm{~kg} / \mathrm{MW} \mathrm{h}$ el abiotic material while hard coal plants consume 1,135 kg/MW $\mathrm{h}_{\mathrm{el}}$ (Wiesen 2010; more comparative data may be found on www.mips-online.de). A comparison shows a significant lower resource use of imported electricity from CSP plants compared to conventional ones.

\subsection{German fuel mix}

The calculated MIPS values for the German fuel mix based on the results of the Desertec scenario assessments are shown in Figure 4. It can be derived that a predominantly renewable fuel mix with a $20 \%$ share of imported solar energy as base load contribution shows a reduction of the resource use between $50 \%$ (air) and $80 \%$ (abiotic material) compared to a mainly conventional fuel mix. Note that the fuel mix 2050 does vary only slightly with CSP building classes. The increase in biotic materials results from an increase in the biomass share in 2050's fuel mix.

The difference between the 2008 and 2010 fuel mix results from differing classification systems of energy sources, differing basis of calculations (which are electricity consumption vs. electricity generation - the difference between them accounts for $40 \mathrm{TW} \mathrm{h}_{\mathrm{e}} / \mathrm{a}$; see above) and from the common difference between reality and scenario. 
The contribution of Desertec to the potential in a reduction of resource use of a mainly renewable fuel mix can be estimated by comparing the share of its resource use with its share in electricity generation: Desertec accounts for e.g. 3-8 \% of the abiotic material use of the 2050 fuel mix while it contributes $20 \%$ of the electrical energy (see Figure 1). Thus, its contribution to the RE potential is rather high.

\section{Conclusion and recommendations}

A number of conclusions and recommendations can be drawn from this investigation regarding an assessment of the natural resource use of the Desertec concept in general and specifically of CSP plants.

Comparing the different building classes of CSP (parabolic, Fresnel, central receiver), the presented results show that central receivers induce the lowest natural resource use. However, this finding needs more detailed analysis concerning the reasons for the higher resource efficiency. The results show furthermore, that in order to reduce the natural resource use of CSP plants, it is a promising option to give special attention to the choice of the location with respect to the necessary effort (in terms of material input) for a sufficient supply with water, and the reduction of transportation. Other options concern more fundamental design decisions, e.g. the support structure (weight and wind area reduction of the collectors reduce the loads to bear).

Another main finding of this study - especially in combination with conclusions from the other studies conducted within the scope of the MaRess project - is the significant lower natural resource use of renewable energies compared to conventional (fossil) fuels.

However, before a decision in favour of Desertec is made, other sources for operating reserve and base load should be investigated with regard to their resource consumption. Examples may be virtual power plants, smart grids, new forms of storage technologies, and operating reserve from pitch controlled wind power plants.

Nevertheless, this study also revealed that there is need for further investigations into some aspects of CSP regarding their natural resource use.

The water consumption of different cooling technologies depending on local environmental conditions (temperature, humidity, etc.) has to be examined. The impact of different ground types regarding the specification of the grounding needs to be investigated as well. As mentioned above, the advantages of central receivers compared to parabolic and Fresnel troughs in terms of resource consumption need explanation, especially regarding the questions where these advantages result from, whether these vary with manufacturer and what conclusions can be drawn for the other building classes. The water saving effect of the automated Novatec Fresnel trough dry cleaning system has to be investigated. For all building classes, further investigation of the environmental impacts of dismantling CSP plants respectively reuse approaches are needed since there is no practical experience with it yet.

The grid expansion implied by the transition to a renewable fuel mix using either a central approach or a decentralised one has to be analyzed and compared.

Solar desalination is a possible expansion of the Desertec concept but its impacts regarding resource consumption have not been investigated so far.

Summed up, it can be stated that solar thermal power and renewable energies in general contribute to both: the reduction of GHG emissions and the reduction of resource consumption. 


\section{Table Captions}

Table 1: Top ten input materials according to their share in use of abiotic materials at a central receiver plant, and the corresponding material intensity (MI) factors

\begin{tabular}{lllllll}
\hline & \multicolumn{2}{l}{ Abiotic material } & \multicolumn{2}{c}{ Water } & & \\
Component & Share & Ml factor & Share & Ml factor & Share & MI factor \\
\hline $\mathrm{KNO}_{3}$ & $45.5 \%$ & $8.2 \mathrm{~kg} / \mathrm{kg}$ & $8.2 \%$ & $59.0 \mathrm{~kg} / \mathrm{kg}$ & $48.1 \%$ & $0.7 \mathrm{~kg} / \mathrm{kg}$ \\
Water, unspecific & $25.4 \%$ & $0.0 \mathrm{~kg} / \mathrm{kg}$ & $82.8 \%$ & $1.3 \mathrm{~kg} / \mathrm{kg}$ & $0.0 \%$ & $0.0 \mathrm{~kg} / \mathrm{kg}$ \\
Concrete & $7.7 \%$ & $1.3 \mathrm{~kg} / \mathrm{kg}$ & $0.5 \%$ & $3.4 \mathrm{~kg} / \mathrm{kg}$ & $3.4 \%$ & $0.0 \mathrm{~kg} / \mathrm{kg}$ \\
Water, deionized & $5.3 \%$ & $0.1 \mathrm{~kg} / \mathrm{kg}$ & $3.6 \%$ & $2.2 \mathrm{~kg} / \mathrm{kg}$ & $8.7 \%$ & $0.0 \mathrm{~kg} / \mathrm{kg}$ \\
Steel, unalloyed & $3.4 \%$ & $1.5 \mathrm{~kg} / \mathrm{kg}$ & $3.4 \%$ & $58.8 \mathrm{~kg} / \mathrm{kg}$ & $15.9 \%$ & $0.5 \mathrm{~kg} / \mathrm{kg}$ \\
Copper & $3.2 \%$ & $179.1 \mathrm{~kg} / \mathrm{kg}$ & $0.2 \%$ & $236.4 \mathrm{~kg} / \mathrm{kg}$ & $0.2 \%$ & $1.2 \mathrm{~kg} / \mathrm{kg}$ \\
Cast iron & $2.8 \%$ & $7.6 \mathrm{~kg} / \mathrm{kg}$ & $0.5 \%$ & $56.0 \mathrm{~kg} / \mathrm{kg}$ & $2.0 \%$ & $0.4 \mathrm{~kg} / \mathrm{kg}$ \\
Excavation & $2.7 \%$ & $1.0 \mathrm{~kg} / \mathrm{kg}$ & $0.0 \%$ & $0.0 \mathrm{~kg} / \mathrm{kg}$ & $0.0 \%$ & $0.0 \mathrm{~kg} / \mathrm{kg}$ \\
Glass & $2.3 \%$ & $3.0 \mathrm{~kg} / \mathrm{kg}$ & $0.2 \%$ & $11.7 \mathrm{~kg} / \mathrm{kg}$ & $7.7 \%$ & $0.7 \mathrm{~kg} / \mathrm{kg}$ \\
Steel, high-alloyed & $0.5 \%$ & $17.9 \mathrm{~kg} / \mathrm{kg}$ & $0.2 \%$ & $240.3 \mathrm{~kg} / \mathrm{kg}$ & $1.3 \%$ & $3.4 \mathrm{~kg} / \mathrm{kg}$ \\
\hline
\end{tabular}

Table 2: Specifications of investigated CSP plants according to Viebahn et al. (2008)

\begin{tabular}{|c|c|c|c|c|}
\hline \multicolumn{2}{|l|}{ Plant } & $\begin{array}{l}\text { Parabolic trough } \\
\text { (Inditep) }\end{array}$ & $\begin{array}{l}\text { Fresnel trough } \\
\text { (Novatec) }\end{array}$ & $\begin{array}{l}\text { Central receiver } \\
\text { (Solar Tres) }\end{array}$ \\
\hline \multicolumn{2}{|c|}{ Full load hours (operation mode solar only) } & 6,400 & 6,400 & \\
\hline \multicolumn{2}{|c|}{ Heat transfer fluid } & Steam & Steam & Molten salt \\
\hline \multicolumn{2}{|c|}{ Heat storage } & PCM & PCM & Molten salt \\
\hline \multicolumn{2}{|c|}{ Storage period (h) } & 16 & 16 & 16 \\
\hline \multirow[t]{2}{*}{2025} & Load $\left(\mathrm{MW}_{\mathrm{el}}\right)$ & 200 & 200 & 180 \\
\hline & Annual efficiency total (\%) & 19 & 11,9 & 18 \\
\hline \multirow[t]{2}{*}{2050} & Load $\left(\mathrm{MW}_{\mathrm{el}}\right)$ & 400 & 400 & 180 \\
\hline & Annual efficiency total (\%) & 19 & 11,9 & 18 \\
\hline
\end{tabular}

Table 3: Locations and power line routes

\begin{tabular}{|c|c|c|c|c|}
\hline \multicolumn{3}{|r|}{ Morocco } & Tunisia & Egypt \\
\hline \multicolumn{2}{|c|}{$\mathrm{DNI}^{*}\left(\mathrm{~kW} \mathrm{~h} /\left(\mathrm{m}^{2 \star} \mathrm{a}\right)\right)$} & 2,011 & 2,103 & 2,232 \\
\hline \multirow{2}{*}{ HVDC } & Overhead line $(\mathrm{km})$ & 405 & 1,399 & 2,510 \\
\hline & Subsea cable $(\mathrm{km})$ & 18 & 373 & 30 \\
\hline
\end{tabular}

$\left.{ }^{*}\right)$ Source for direct normal irradiance (DNI) data is Meteonorm 6.1.0.15. 
Table 4: Building steps in assumed Desertec implementation according to DLR 2006

\begin{tabular}{lll}
\hline Year & Transfer power $\left(\mathrm{GW}_{\mathrm{el}}\right)$ & Transfer energy $\left(\mathrm{TW} \mathrm{h}_{\mathrm{el}} / \mathrm{a}\right)$ \\
\hline $2030^{*}$ & $8 \times 5$ & 230 \\
2050 & $20 \times 5$ & 700 \\
\hline
\end{tabular}

$\left.{ }^{*}\right)$ This year is assigned to the 2025 plant technology development scenario (see above).

Table 5: German fuel mix 2008, 2010 and 2050 according to Wiesen (2010) and DLR (2006)

\begin{tabular}{|c|c|c|c|c|}
\hline German fuel mix in & 2008 (real) & 2010 (scenario) & 2050 (scenario) & \\
\hline Wind & $6.6 \%$ & $5.7 \%$ & $25.1 \%$ & \\
\hline Photovoltaics & $0.6 \%$ & $0.1 \%$ & $4.0 \%$ & \\
\hline Geothermal & $0 \%$ & $0.1 \%$ & $3.8 \%$ & \\
\hline Biomass & $4.9 \%$ & $2.2 \%$ & $10.7 \%$ & \\
\hline Wave / tidal & - & $0.0 \%$ & $0.6 \%$ & \\
\hline Hydro power & $3.5 \%$ & $3.5 \%$ & $4.4 \%$ & \\
\hline Oil & $5.8 \%$ & $1.2 \%$ & $0.0 \%$ & \\
\hline Gas & $12.9 \%$ & $16.1 \%$ & $7.1 \%$ & \\
\hline Coal & $42.7 \%$ & $49.5 \%$ & $16.9 \%$ & \\
\hline Nuclear & $23.0 \%$ & $15.1 \%$ & $0.0 \%$ & \\
\hline Import Others & - & $6.5 \%$ & $7.1 \%$ & \\
\hline Import Solar & - & $0.0 \%$ & $20.3 \%$ & \\
\hline \multicolumn{5}{|c|}{$\begin{array}{l}\text { Note that the } 2008 \text { data is based on electricity consumption whereas the } 2010 \text { and } \\
2050 \text { data are based on electricity generation and import. }\end{array}$} \\
\hline \multicolumn{5}{|c|}{ Table 6: Calculated MIPS values for the Desertec scenarios } \\
\hline $\begin{array}{l}\text { Assumed building class for } \\
\text { Desertec }\end{array}$ & Abiotic materials & Water & & Air \\
\hline Central Receiver & $120 \mathrm{~kg} / \mathrm{MW} \mathrm{h} \mathrm{el}$ & $4,928 \mathrm{k}$ & /MW $\mathrm{h}_{\mathrm{el}}$ & $9 \mathrm{~kg} / \mathrm{MW} \mathrm{h} \mathrm{h}_{\mathrm{el}}$ \\
\hline Parabolic Trough & $208 \mathrm{~kg} / \mathrm{MW} \mathrm{h} \mathrm{el}$ & $6,462 k$ & g/MW hel & $16 \mathrm{~kg} / \mathrm{MW} \mathrm{h} \mathrm{h}_{\mathrm{el}}$ \\
\hline Fresnel Trough & $198 \mathrm{~kg} / \mathrm{MW} \mathrm{h} \mathrm{el}$ & $9,175 \mathrm{k}$ & /MW $\mathrm{h}_{\mathrm{el}}$ & $13 \mathrm{~kg} / \mathrm{MW} \mathrm{hel}$ \\
\hline
\end{tabular}




\section{Figure Captions}

Figure 1: German fuel mix in 2010 and 2050 (TWh/year); source: compiled by the author

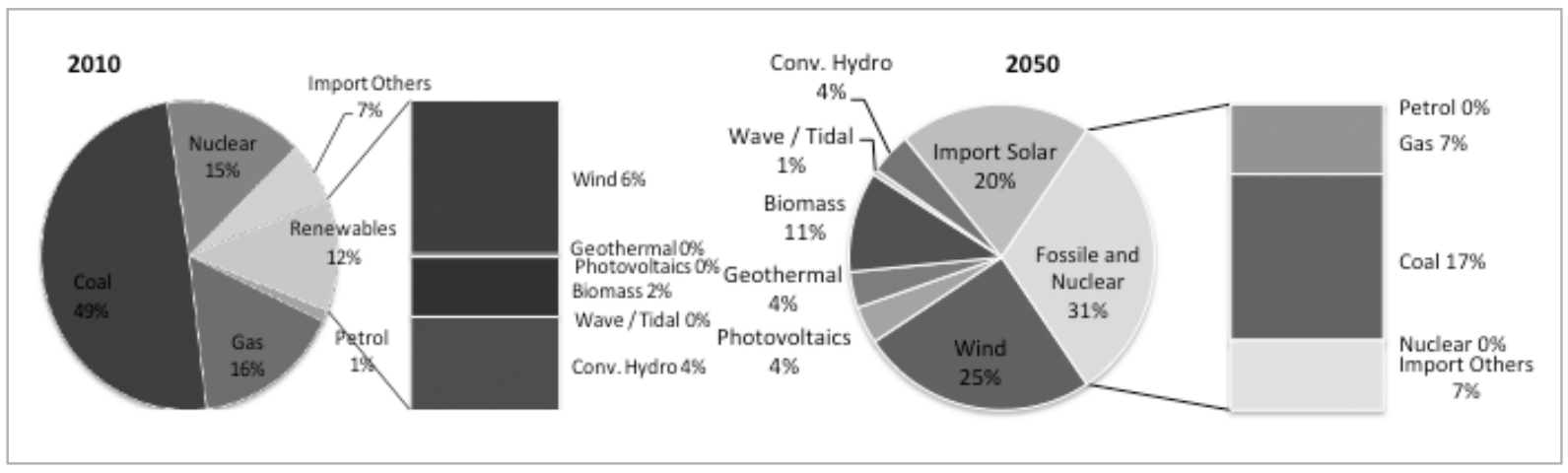

Figure 2: Resource (MIPS categories abiotic materials, water, air) use of CSP plants at the Moroccan location in 2025; source: compiled by the author

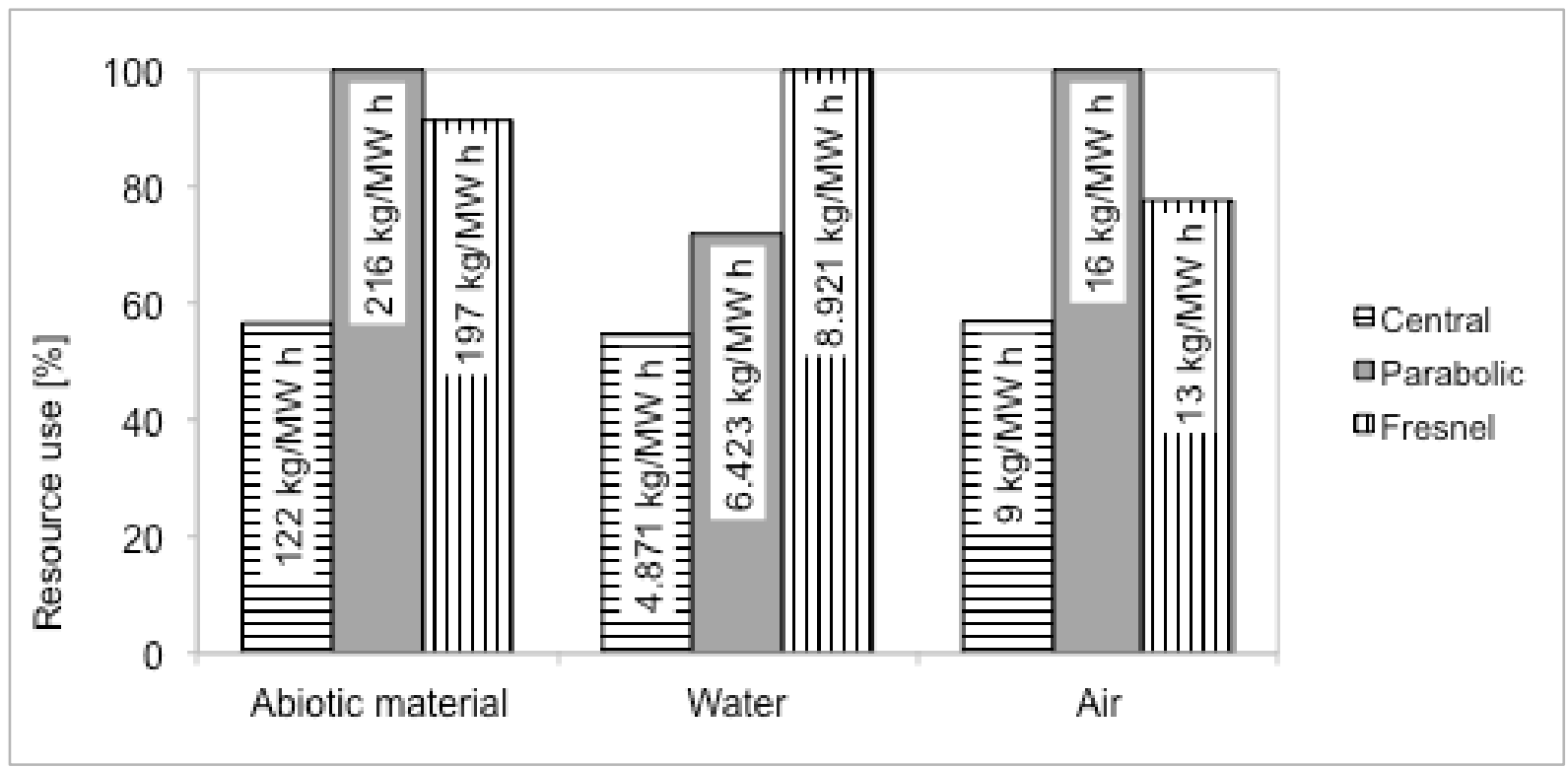

Figure 3: Top 5 materials according to share in resource use of CSP plant at Moroccan location in 2025; source: compiled by the author

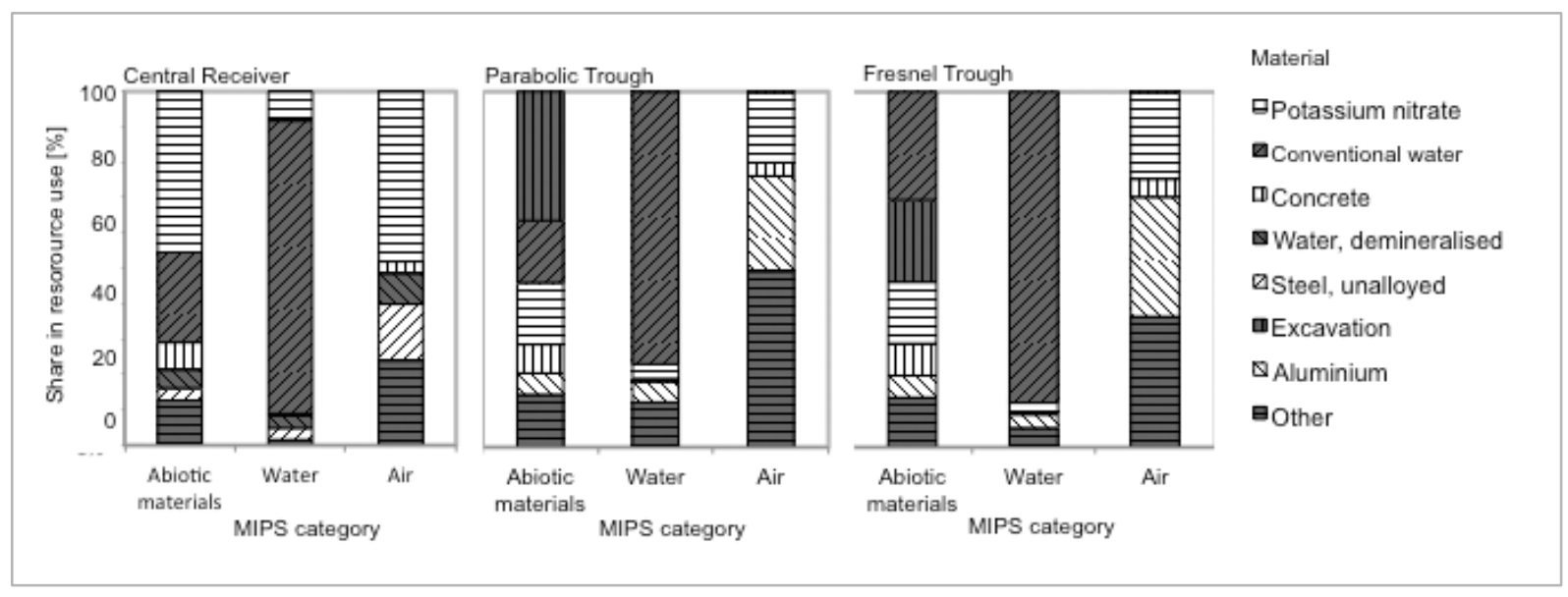


Figure 4: Resource use of the German fuel mix in 2008, 2010 and 2050; source: compiled by the author

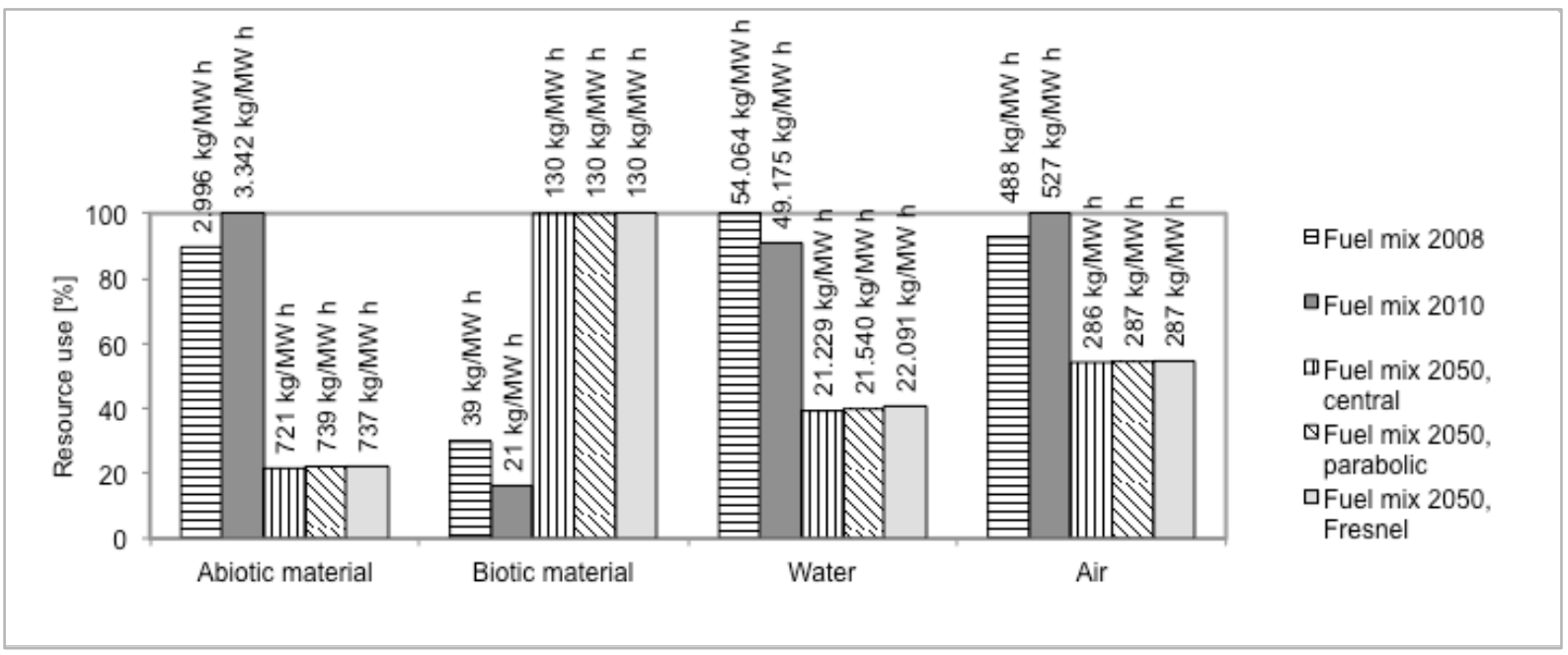

\section{References}

BMU - Federal Ministry for the Environment, Nature Conservation and Nuclear Safety (Eds.), 2008. Weiterentwicklung der Ausbaustrategie Erneuerbare Energien - Leitstudie 2008. BMU, Berlin.

BMU - Federal Ministry for the Environment, Nature Conservation and Nuclear Safety (Eds.), 2009. Erneuerbare Energie in Zahlen - Nationale und internationale Entwicklung. BMU, Berlin.

bpb - Bundeszentrale für politische Bildung (Eds.), 2008. Klimagerechtigkeit. Themenblätter im Unterricht Nr.73. <http://www.bpb.de/files/BIFWHV.pdf> (accessed 14 January 2011)

Dersch, J., Richter, C., 2010. Wasserverbrauch und Wassereinsparung bei solarthermischen Kraftwerken. Presentation at the $13^{\text {th }}$ DLR cologne sun congress. $<$ http://www.dlr.de/tt/en/Portaldata/41/Resources/dokumente/soko2010/PDF-

Format/7_Dersch_Wasserverbrauch_Wassereinsparung.pdf> (accessed 17 January 2011)

Desertec Foundation (Eds.), 2009. Red Paper - An Overview of the Desertec Concept. $<$ http://www.desertec.org/fileadmin/downloads/desertec-foundation_redpaper_3rdedition_english.pdf> (accessed 14 January 2011)

DLR - Deutsches Zentrum für Luft- und Raumfahrt (Eds.), 2006. Trans-Mediterranean Interconnection for Concentrating Solar Power: TRANS-CSP. DLR, Stuttgart.

Fricke, B., 2007.Vergleich der Zukunftsfähigkeit eines Solarturm-Kraftwerks mit der anderer Energiekonverter anhand des Material-Inputs-Pro-Serviceeinheit (MIPS) und des kumulierten Energieaufwands (KEA). FH Aachen, Aachen.

Hendriks, C., Geurder, N., Viebahn, P., Steinsiek, F., Spies, J., 2004. Solar Power from Space: European Strategy in the Light of Sustainable Development - Phase 1: Earth and Space based power gen-eration systems. Ecofysbv, Utrecht.

Intergovernmental Panel on Climate Change [IPCC] [ed.], 2005. Contribution of Working Group I to the Fourth Assessment Report of the Intergovernmental Panel on Climate Change. Cambridge University Press, Cambridge. $<$ http://www.ipcc.ch/publications_and_data/publications_ipcc_fourth_assessment_repo rt_wg1_report_the_physical_science_basis.htm> (accessed 08 November 2011) 
International Energy Agency [IEA] [ed.], 2010. World Energy Outlook 2010. IEA, Paris. <http://www.worldenergyoutlook.org/docs/weo2010/WEO2010_es_english.pdf> (accessed 08 November 2011)

Lang-Koetz, C., Pastewski, N., Rohn, H., 2010. Identifying New Technologies, Products and Strategies for Resource Efficiency. In: Chemical Engineering and Technology, 2010, 33, No. 00, 1-9. WILEY-VCH Verlag GmbH \& Co. KGaA, Weinheim

Lehmann, H., Reetz, T., Roewer, S., Liedtke, C., 1996. Ökologische Chancen und Risiken großtechnisch angelegter solarthermischer Kraftwerke. Wuppertal Institut, Wuppertal.

Lettenmeier, M., Rohn, H., Liedtke, C., Schmidt-Bleek, F., 2009. Resource productivity in 7 steps - How to develop eco-innovative products and services and improve their material footprint. Wuppertal Institute, Wuppertal.

May, N., 2005. Ökobilanz eines Solarstromtransfers von Nordafrika nach Europa. TU Braunschweig, Braunschweig.

Pitz-Paal, R., Dersch, J., Milow, B. (Eds.), 2005. European Concentrated Solar Thermal Road-Mapping (ECOSTAR). Coordinated action sustainable energy systems SES6CT-2003-502578. DLR, Cologne.

Rohn, H., Pastewski, N., Lettenmeier, M., 2010. Resource efficiency of selected technologies, products and strategies. Executive summary. Wuppertal Institute, Wuppertal.

Schmidt-Bleek, F., 1994. Wieviel Umwelt braucht der Mensch? Faktor 10 - das Maß für ökologisches Wirtschaften. Verlag Birkhäuser, Berlin.

Tressner, B.V., 2007. Technologievergleich solarthermischer Stromerzeugung einschließlich global-ökonomischer und -ökologischer Bewertung. FH Köln, Köln.

Trieb, F., O'Sullivan, M., Pregger, T., Schillings, C., Krewitt, W., 2009. Characterisation of Solar Electricity Import Corridors from MENA to Europe: Potential, Infrastructure and Cost. DLR, Stuttgart.

Viebahn, P., Kronshage, S., Trieb, F., Lechon, Y., 2008. NEEDS - New Energy Externalities Developments for Sustainability: Final report on technical data, costs, and life cycle inventories of solar thermal power plants. DLR, Stuttgart.

Viebahn, P., 2004. SOKRATES-Projekt - Solarthermische Kraftwerkstechnologie für den Schutz des Erdklimas. Deutsches Zentrum für Luft und Raumfahrt, Stuttgart.

Weinrebe, G., 2000. Technische, ökologische und ökonomische Analyse von solarthermischen Turmkraftwerken. Universität Stuttgart, Stuttgart.

Wiesen, K., 2010. Ermittlung von Ressourceneffizienzpotenzialen der regenerativen Stromerzeugung durch Windenergie und Biomasse in Deutschland. HAWK, Göttingen.

WWF (Eds.), 2010. Living Planet Report 2010 - Biodiversity, biocapacity and development. <http://assets.panda.org/downloads/lpr2010.pdf> (accessed 31 January 2011) 